\title{
Karlovy Vary 2004
}

\author{
By Ron Holloway
}

Fall 2004 Issue of KINEMA

KARLOVY VARY INTERNATIONAL FILM FESTIVAL 2004

For the Czech media the $39^{\text {th }}$ Karlovy Vary International Film Festival (2-10 July 2004) was something of a sensation. Václav Havel, the country's ex-president and most popular political figure, was on hand for the official opening to receive a moving standing ovation. Later, Václav Klaus, the current Czech president, also showed for the closing ceremonies. To add to the festivities, Miroslav Ondříček, Miloš Forman's ace cameraman (Oscar Nominations for Amadeus and Ragtime) was honoured with an Award for Outstanding Artistic Contribution to World Cinema (together with Harvey Keitel and Roman Polański). The Prize of the Karlovy Vary Region was given for the first time to Jiří Bartoška, the festival codirector. And the Ecumenical Jury honoured Eva Zaoralová, the festival's artistic director, an Award for Outstanding Contribution to the Karlovy Vary International Film Festival.

For the second time in a row, the Crystal Globe, KVIFF's Grand Prix, was awarded to an Italian film: Certi bambini (A Children's Story), directed by Andrea and Antonio Frazzi. The Frazzi brothers thus join the Italian Tavianis (Paolo and Vittorio), the Belgian Dardennes (Luc and Jean-Pierre), and the American Coens (Ethan and Joel) as yet another fraternal directorial team. Specializing in the children-and-youth film, their The Sky Will Fall (1999) was awarded the Special Jury Prize at the Giffoni Children's Film Festival. In A Children's Story, based on a novel by Diego Da Silva, who co-scripted the film, the focus is on 11-year-old Rosario (Arturo Paglia), who lives with an ailing grandmother but prefers to roam the streets of Naples with friends - smoking, sniffing, drinking, stealing. To their credit, the Frazzis don't exploit the lurid side of the theme, as Larry Clark did in Kids and Ken Park. Rather, A Children's Story comes across as a sad, rather melancholic statement about youngsters who have unfortunately already consumed most of their lives before even reaching their teens. One has the feeling, too, that the film is a directorial salute to a Neorealist classic in Italian cinema: Vittorio de Sica's The Children Are Watching Us (1943), the first time of his many collaborations with screenwriter Cesare Zavattini.

Films about youth were the core of a rather weak KVIFF competition lineup. Indeed, nearly all of the prizes awarded by the international jury went in this direction. In Xavier Bermudez's León y Olvida (León and Olvida, Spain), awarded the Best Director Prize, a 20-year-old boy with Down's Syndrome refuses to live in an institution upon the death of his mother and thus places a heavy burden upon his older sister. Marta Larralde as Olvida, the long-suffering sister, well deserved her share of the Best Actress Award. The Best Actor Award went to Max Riemelt for his performance in Dennis Gansel's Napola (Germany), the story of a 17-year-old Berlin youth from a working-man's family whose passion for boxing gains him entrance in 1942 to an elite Nazi school (NAPOLA - Nationalpolitische Erziehungsanstalt). There he makes friends with the sensitive son of a Nazi leader, whose tragic fate opens his eyes to his loss of freedom and self-esteem in the regimented school.

In Zrinko Agresta's Tu (Here, Croatia-Bosnia-Herzegovina), awarded the Special Jury Prize, the Croatian director links six individual stories around the fate of a mentally disadvantaged youth from a village devastated at the outbreak of the Yugoslav War. And in Christophe Barratier's Les choristes (Chorists, France-Switzerland), the return of a famous conductor to attend the funeral of his mother triggers memories of a talented music teacher at a boarding school for unmanageable boys during the postwar years. Using methods to tame wild souls, the choral teacher has to contend with a devil with an angel's voice.

As to be expected, the $39^{\text {th }}$ KVIFF highlighted the current revival of cinematographies in ex-socialist countries. Valery Todorovsky's Moy svodny brat Frankenstejn (My Step-Brother Frankenstein, Russia), awarded the FIPRESCI (International Critics) Prize, takes the pulse of a troubled Moscow in the wake of the war in Chechnya when a war veteran appears suddenly on the scene to upset a physicist's complacent family life. Vinko Bresan's Svjedoci (Witnesses, Croatia), awarded the prestigious Philip Morris Prize in the East of the West section, chronicles contrasting and contradictory viewpoints about the murder of a Serb in a Croatian village in a what-is-truth Rashomon context. Indeed, the East of the West section was packed to the brim 
with outstanding entries, many of which had already been awarded and cited at major international film festivals: Marina Razbezhkina's Vremya shatvy (Reaping the Harvest, Russia), Guka Omarova's Shizza (Schizo) (Kazakhstan-Russia-France-Germany), Alexei Gherman Jr's Posledny Poyezd (The Last Train, Russia), Nariman Turebayev's Malenkie Lyudi (Little Men, Kazakhstan-France), Sinisa Dragin's Faraonul (Pharaoh, Romania), Krasimir Krumov's Pod edno nebe (Under the Same Sky, Bulgaria), and Kako ubiv svetec (How I Killed a Saint, Macedonia-Slovenia-France).

Two Eastern films by students at film schools were popular hits in other sections. Die Geschichte vom weinenden Kamel (The Story of the Weeping Camel, Mongolia-Germany) by Byambasuren Davaa and Luigi Falorni, graduates of the Munich Film School, was programmed in the Another View section and voted the Právo Audience Prize. Set on the steppes of Mongolia, this warm-hearted story of how musicians coax a mother camel to allow her newly born offspring to suckle for milk. And Vít Klusák and Filip Remunda, graduates of the Prague Film School (FAMU) hit the jackpot with their documentary Český sen (Czech Dream), programmed in the Czech Film 2003-2004 section. Czech Dream documents in uproarious fashion the marketing of a consumer hoax. For two weeks in May of 2003 the people of Prague were saturated with advertising for the opening of a "hypermarket for better life" super-store for eager-beaver shoppers. And, of course, 5000 people showed up on an open field before a huge façade dominated by a "Czech Dream" logo, some arriving at dawn with camping-chairs to be the first in line for the grand opening. A delight to watch as the hoax unfolds, Czech Dream also provoked not only pro-and-contra opinion in the media, but it was also discussed in the Czech Parliament!

Karlovy Vary 2004 was also the scene of a festival contretemps with FIAPF (International Federation of Film Producers Associations), the organization in charge of competition regulations for member festivals. According to one media account, when Karlovy Vary invited Metod Pevec's Pod njenim oknom (Beneath Her Window, Slovenia) to participate in the competition, FIAPF was informed well in advance of the decision, and FIAPF gave its approval. Later, smack in the middle of the Karlovy Vary festival, that permission was withdrawn by FIAPF's Bertrand Mollier on the grounds that Beneath Her Window had already participated in the Kingfisher Competition in the Slovenian capital at the Ljubljana International Film Festival last November. Accordingly, Eva Zaoralová dropped the film from the Karlovy Vary competition - only to have the film's producer, Danijel Hocevar, send a complaint through the Slovenian Producers Association to the FIAPF headquarters on the grounds that Slovenian producers have every right to program their own films in their own national festival - a rule, that FIAPF traditionally honours. Mollier, now in the middle of the affair, reportedly responded that his "decision" was only a "recommendation" - and nothing more. In that case, why would FIAPF even bother to stir the waters of controversy right in the middle of one of the world's most respected film festivals? As one FIPRESCI critic remarked, the letters of FIAPF should now stand for "Festival Institution for Asinine Protection of Favourites" - meaning that Karlovy Vary may have become a bit too "competitive" for other festival members with more pull at the FIAPF headquarters.

\section{References}

\section{AWARDS}

\section{INTERNATIONAL COMPETITION}

Crystal Globe - Grand Prix:

Certi bambini (A Children's Story, Italy), Andrea and Antonio Frazzi

Special Jury Prize:

Tu (Here, Croatia-Bosnia-Herzegovina), Zrinko Ogresta

Best Director:

Xavier Bermudez, León y Olvida (León and Olvida, Spain)

Best Actress (ex aequo)

Karen-Lisa Mynster, Lad de små børn (Aftermath, Denmark), dir Paprika Steen

Marta Larralde, León y Olvida (León and Olvida, Spain), dir Xavier Bermudez 
Best Actor:

Max Riemelt, Napola (Germany), dir Dennis Gansel

DOCUMENTARY COMPETITION

Best Documentary Film:

Svadba tishiny (Wedding of Silence, Russia), Pavel Medvedev

Special Mention:

Untertage (Days Under, Netherlands), Jiska Rickels

Ničeho nelituji (No Regrets, Czech Republic), Theodora Remundova

Awards for Outstanding Artistic Contribution to World Cinema

Harvey Keitel (USA), Miroslav Ondříček (Czech Republic), Roman Polański (France-Poland)

Prize of Town of Karlovy Vary

Jacqueline Bisset (USA)

Prize of Karlovy Vary Region

Jiří Bartoška (Czech Republic)

Philip Morris Film Award (250,000 CZK)

Svjedoci (Witnesses, Croatia), Vinko Bresan

Ecumenical Prize

Cavedweller (USA), Lisa Cholodenko

Ecumenical Jury Award for Outstanding Contribution to KVIFF

Eva Zaoralová (Czech Republic)

International Critics (FIPRESCI) Prize

Moy svodny brat Frankenstejn (My Step-Brother Frankenstein, Russia), Valery Todorovsky

Don Quixote Prize (FICC - International Federation of Film Clubs)

Kenar-e roodkhaneh (Riverside, Iran), Ali-Reza Amini

Special Mention

Lad de små børn (Aftermath, Denmark), Paprika Steen

Pravo Audience Prize

Die Geschichte vom weinenden Kamel (The Story of the Weeping Camel, Germany-Mongolia), Byambasuren Davaa, Luigi Falorni

Czech Television Award - Independent Camera Prize

Best Film in Forum of Independents

Dandelion (USA), Mark Milgard

\section{Author Information}

Ron HOLLOWAY (1933-2009) was an American critic, film historian, filmmaker and correspondent who adopted Europe as his home in the early fifties and spent much of his life in Berlin. He was an expert on the study of German cinema and against all odds produced, with his wife Dorothea, the journal German Film, keeping us up-to-date with the work of directors, producers and writers and the showing of German films around the world.

In 2007, Ron Holloway and his wife were awarded the Berlinale Camera Award. Ron also received the Bundesverdienstkreuz (German Cross of Merit), Polish Rings, Cannes Gold Medaille, the American Cinema Foundation Award, the Diploma for Support of Russian Cinema and an honorary award from the German Film Critics' Association.

Ron was also a valued contributor to Kinema for the past fifteen years. 